\title{
Communication
}

[Comunicação]

\section{Ultrasound-guided biopsy of the equine forelimb proximal suspensory ligament by longitudinal access}

[Biópsia guiada por ultrassom da origem do ligamento suspensor do boleto de equinos por acesso longitudinal]

\author{
R.Y.A. Baccarin, C.P. Vendruscolo, B. Cogliati, A.G.R. Schultz, \\ C.A.S. La Torre, P.A.R. Ramos
}

\section{Faculdade de Medicina Veterinária e Zootecnia - Universidade de São Paulo - - Butantã, SP}

The superficial digital flexor tendon is the most commonly affected component of the equine suspensory apparatus, but increasing recognition of suspensory ligament (SL) injuries and their impact on athletic performance have drawn special attention to this structure (Giunta et al., 2019). The equine SL, especially at its origin, has unique histological features and is not as readily accessible as other adjacent elements of the suspensory apparatus (Werpy and Denoix, 2012).

Ultrasonography is the most common technique used to diagnose proximal SL injury, but MRI images may be necessary to obtain a definitive diagnosis in cases where the disease does not affect echogenicity enough to make it discernible with ultrasound (Werpy and Denoix, 2012). However, morphological and biochemical techniques could be more appropriate for characterizing the healing process and assessing treatment efficiency compared with imaging modalities. Furthermore, the most effective method to detect and describe collagen fiber orientation is by their physical properties (birefringence) (Vidal and Carvalho, 1990; Santos, 2004; Spiesz et al., 2018). Some studies (Cunha et al., 2001; Santos, 2004; Koeke et al., 2005) have shown that polarized light microscopy is the most appropriate method to determine collagen fiber organization, state of aggregation, and molecular order qualitatively and quantitatively.

Recebido em 27 de junho de 2019 Aceito em 27 de novembro de 2019 E-mail : baccarin@usp.br
Collagen is an anisotropic material: whenever collagen fibers are aligned perfectly transverse to the direction of light propagation, there is a change in the refraction of light resulting in maximum brightness. When collagen fibers are aligned along the axis of light propagation, no refraction occurs and it appears dark or extinct, and fibers having intermediate orientations appear as different shades of grey (Bromage et al., 2003).

The complicated anatomy of the proximal SL makes it difficult to perform biopsy. In addition to understanding the anatomy of the ligament, it is important to recognize its anisotropy for birefringence analysis purposes and therefore, longitudinal access is necessary.

The aim of this article is to describe and illustrate an easy approach to the proximal SL that enables tissue sample collection for histological and/or immunohistochemical analysis as well as for birefringence analysis through longitudinal access.

The experimental protocol was approved by the Institutional Animal Care and Use Committee (protocol number 2284/2011). For technique design, six forelimbs from horses euthanized for reasons other than the study were used. For the in vivo portion of the study, 18 healthy crossbreed horses aged 4 to 12 years, 14 mares and 4 gelding horses without a history of SL lesions and clinically and ultrasonographically healthy according to Baxter and Stashak (2011) and Smith and Cauvin (2014) were used. All horses 
were cared for according to IACUC standard standards and guidelines and were adopted by private individuals upon conclusion of the study.

Prior to the procedure, the lateral palmar nerve was anesthetized with $3 \mathrm{ml}$ of $3 \%$ mepivacaine hydrochloride (Mepisv 3\%, Nova DFL, Rio de Janeiro, Brazil) using a $2.5 \mathrm{~cm}$ x $21 \mathrm{G}$ needle, inserted at the medial aspect of the accessory carpal bone perpendicular to the skin (Moyer et al., 2011).

The hair was clipped from the palmar and lateral sides of the third metacarpal bone (MCIII) region, and the skin was aseptically prepared to ensure sterility. A surgical glove with $10 \mathrm{ml}$ of gel inside was used to cover the probe (Fig. 1). Contact between the probe and skin was established using $70 \%$ ethyl alcohol.

After the horse was sedated with detomidine $0.02 \mathrm{mg} / \mathrm{kg} \mathrm{IV}$, the forelimb was held, and the carpus was flexed at an articular angle of $90^{\circ}$. The superficial digital flexor tendon (SDFT), the deep digital flexor tendon (DDFT) and the accessory ligament of the DDFT (ALDDFT) were in relaxed positions and could be displaced medially with the probe. A linear array transducer (7.5 to $12 \mathrm{mHz}$, ESAOTE MyLab30 Gold Vet) was then positioned longitudinally and slightly obliquely to the SL, close to the fourth metacarpal head and as a result, the SL appeared just above the surface line of the MCIII in the ultrasound image. The site of the biopsy needle (Pro-Mag Ultra, 18G x $15 \mathrm{~cm}$ ) entrance was located 10 to $13 \mathrm{~cm}$ distal to the accessory carpal bone. It was a half to one centimeter distal to the probe, at a $20^{\circ}$ angle, longitudinally, in relation to the ligaments' fibers. The biopsy needle reached the proximal region of the SL approximately $7 \mathrm{~cm}$ distal to the accessory carpal bone, progressing in a proximal direction 3 to 4 $\mathrm{cm}$. At this point, it was possible to perform the biopsy with the device Pro-Mag TM Ultra automatic Biopsy System (Ecomed, São Paulo, Brazil) (Fig. 1A and Fig. 1B), and a small fragment, measuring approximately 5-10 mm, was obtained.

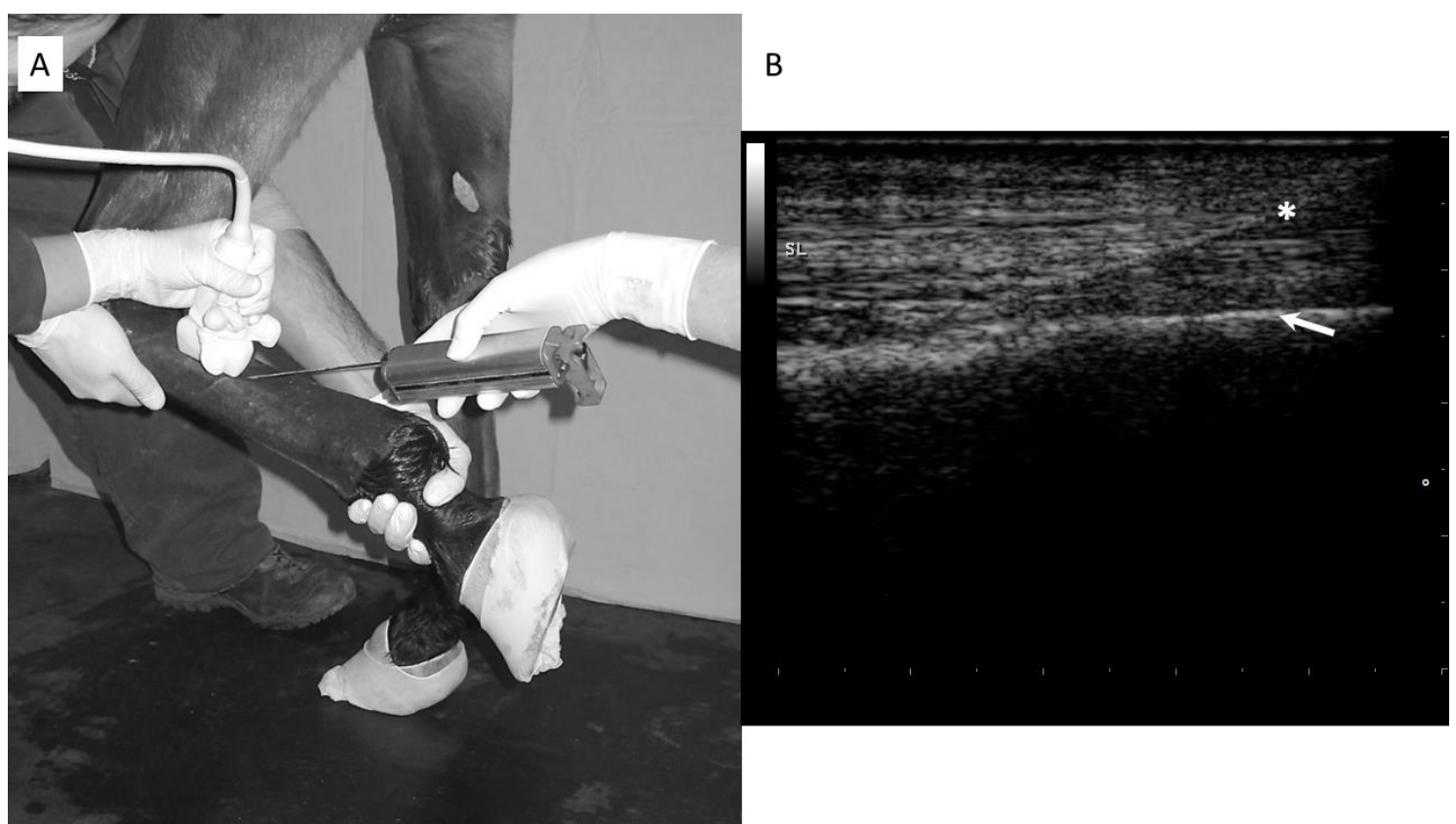

Figure 1. Ultrasound-guided biopsy of the equine forelimb proximal suspensory ligament. (A) The flexor tendons were displaced medially with the probe, and the biopsy needle was introduced $10-13 \mathrm{~cm}$ distal to the accessory carpal bone and a half to one centimeter distal to the probe at an angle of 20 degrees. At this point, the biopsy was performed using the device Pro-Mag TM Ultra automatic Biopsy System (B) The biopsy needle $(*)$ appears in the ultrasound image crossing the equine proximal suspensory ligament above the third metacarpal bone (arrow), proximal to the left and distal to the right. 
In the forelimb, the SL is innervated by palmar metacarpal nerves, derived from the lateral palmar nerve, which receives fibers from both ulnar and median nerves (Moyer et al., 2011). The perineural block of the lateral palmar nerve desensitizes the proximal part of the SL and the lateral side of the metacarpal region. Moreover, it desensitizes the skin at the lateral aspect for needle entry, thus ensuring that the horses do not react to the procedure.

In addition, with the limb in flexion and the tendon sheath maintaining adjacency of the flexor tendons, they were easily medially displaced with the probe, as was confirmed in cadaveric specimen dissections. During the in vivo portion of the study, with the forelimb in flexion and the flexor tendons medially displaced with the probe, the image of the SL appeared just above the MCIII hyperechoic line. Rarely, the accessory ligament of the deep digital flexor tendon may appear in the image without any other structure interfering.

The biopsy technique we used was developed as an approach to access the proximal SL and obtain a representative tissue fragment of good quality by biopsy in a controlled experimental trial. With the biopsy needle we collected a representative sample of tissue from which we performed a histological evaluation of the healing process and collagen fiber organization by birefringence analysis (Fig. 2A and 2B). There were size variations according to the texture of the tissue, meaning: softer tissues provided smaller fragments and harder tissues provided bigger ones.

The horses were monitored for 7 days postprocedure for any sign of adverse reaction such as edema, bleeding, lameness, local pain, or any comorbidities, and no reaction was observed, as reported in equine tendons by Wagels et al. (2001). In the ultrasound image taken soon after the biopsy, the only observation noted was the shadow of the biopsy needle, which was no longer observed the following day, as shown in Fig. 3.
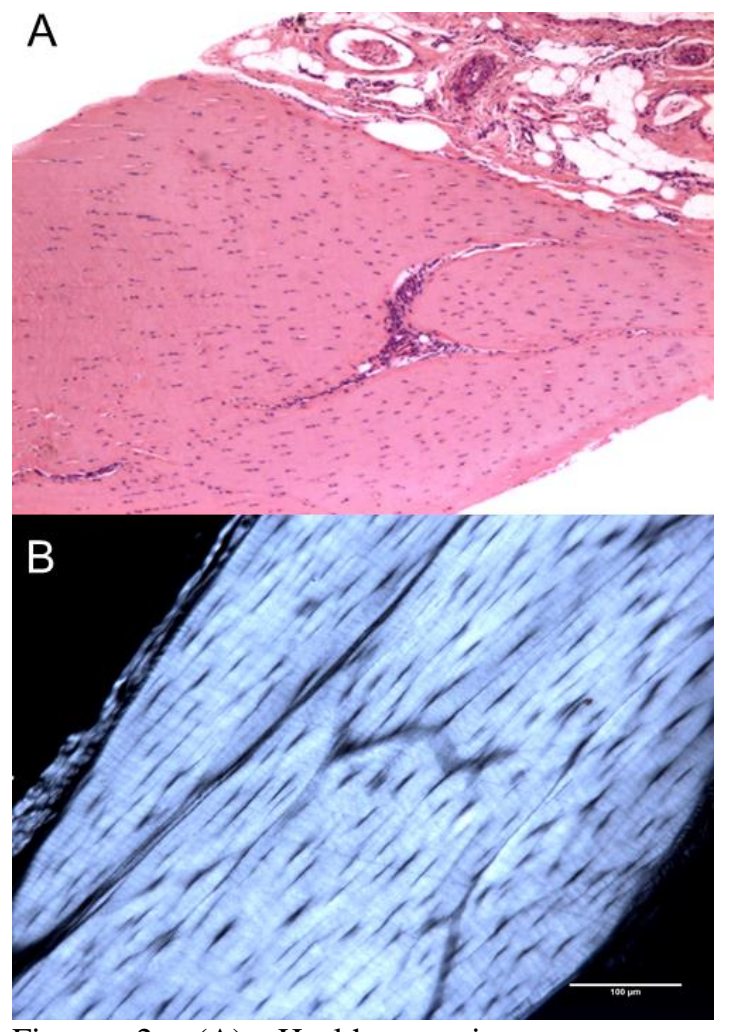

Figure 2. (A) Healthy equine suspensory ligament sample collected by biopsy needle showing sufficient size and quality to perform histopathological analysis. H\&E 40x. (B) Birefringence image of SL sample. The collagen fibers were arranged at approximately $45^{\circ}$ with respect to the polarizers, original magnification $\mathrm{x}$ 20.

Results of this histological examination could influence the guidelines for a return to exercise program, diminishing the probability of ligament reinjury. This technique can be used to evaluate experimental procedures in a standing position under sedation, thus avoiding general anesthesia, surgical procedure, post-operative bandage and, in some cases, the need to subject the horses to euthanasia. Regarding clinical cases, this technique could be used in situations of delayed healing of the proximal suspensory ligament or recurrence of short-term lesions. 


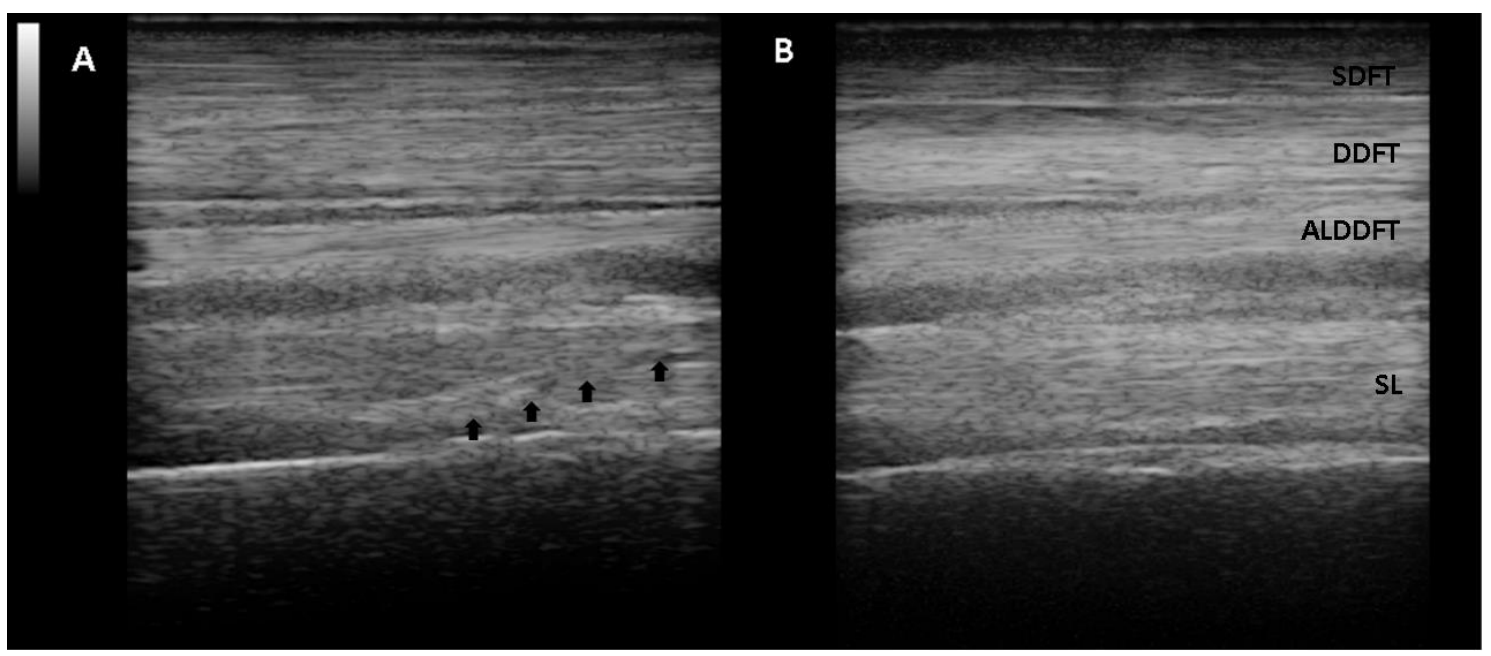

Figure 3. Longitudinal ultrasonographic image of the equine proximal metacarpal region. Images were obtained using the standard technique with the limb weight bearing, without a standoff pad (A) Ultrasound image immediately after the biopsy showing the shadow of the biopsy needle (black arrows) in the suspensory ligament. (B) Ultrasound image $24 \mathrm{~h}$ after biopsy showing a normal suspensory ligament. Superficial digital flexor tendon (SDFT); deep digital flexor tendon (DDFT); accessory ligament of DDFT (ALDDFT); and suspensory ligament (SL).

The technique used is a safe and easy procedure for biopsy of the proximal SL and for obtaining tissue samples of good quality and size. Additionally, it could be used in the creation of a protocol for an experimental desmitis model, for instance, or for research or clinical practice.

Keywords: horse, ligament, biopsy

\section{RESUMO}

A literatura atual discute múltiplas modalidades de imagem para acompanhar o processo de cicatrização da origem do ligamento suspensor do boleto (LSB) em equinos, mas nenhuma pode garantir que eles possuam fibras colágenas com calibre suficiente para suportar o retorno ao exercício. Já as técnicas morfológicas e bioquímicas, bem como a análise de birrefringência, podem ser mais apropriadas para caracterizar o processo de cicatrização e avaliar a eficiência do tratamento. O objetivo deste artigo é descrever procedimento simples que possibilita a coleta de amostras teciduais de boa qualidade e em sentido longitudinal, por biópsia em equinos em estação. Após antissepsia local, sedação e bloqueio do nervo palmar lateral no aspecto medial do osso acessório do carpo (OAC), o membro foi colocado em suspensão com o carpo flexionado em $90^{\circ}$; a agulha de biópsia guiada por ultrassom foi introduzida em sentido distoproximal, 11 a $13 \mathrm{~cm}$ distal ao OAC, ângulo de $20^{\circ}$ em relação ao LSB, até a região de sua origem. O equipamento foi disparado e coletou-se a amostra tecidual. Essa técnica possibilitou a coleta de fragmentos de boa qualidade para análise histológica e de birrefringência, sem reações adversas, podendo ser usada em modelos experimentais ou na prática clínica.

Palavras-chave: cavalo, ligamento, biópsia

\section{ACKNOWLEDGMENTS}

This research was supported by Fundação Coordenação de Aperfeiçoamento de Pessoal de Nível Superior (CAPES Finance code 001),
Brasília, DF, Brazil and Fundação de Amparo a Pesquisa do Estado de São Paulo (FAPESP), São Paulo, SP, Brazil. These sponsors did not have any influence on the study design or the collection, analysis or interpretation of the data. 


\section{REFERENCES}

BAXTER, G.M.; STASHAK, T.S. History, visual exam, palpation, and manipulation. In: BAXTER, G.M. (Ed.). Adams \& Stashak's Lameness in horses. 6.ed. Chichester: WilleyBlackwell, 2011. p.109-150.

BROMAGE, T.G.; GOLDMAN, H.M.; MCFARLIN, S.C. et al. Circularly polarized light standards for investigations of collagen fiber orientation in bone. Anat Rec, v.274B, p.157-168, 2003.

CUNHA, A.; PARIZOTTO, N.A.; VIDAL, B.C. The effect of therapeutic ultrasound on repair of the achilles tendon (tendo calcaneus) of the rat. Ultrasound Med. Biol., v.27, p.1691-1696, 2001.

GIUNTA, K.; DONNELL, J.R.; DONNELL, A.D. et al. Prospective randomized comparison of platelet rich plasma to extracorporeal shockwave therapy for treatment of proximal suspensory pain in western performance horses. Res. Vet. Sci., v.126, p.38-44, 2019.

KOEKE, P.U.; PARIZOTTO, N.A.; CARRINHO, P.M. et al. Comparative study of the efficacy of the topical application of hydrocortisone, therapeutic ultrasound and phonophoresis on the tissue repair process in rat tendons. Ultrasound Med. Biol., v.31, p.345-350, 2005.

MOYER, W.; SCHUMACHER, J.; SCHUMACHER, J. Equine joint injection and regional anesthesia. 2.ed. Chadds Ford, PA: Academic Veterinary Solutions, 2011. 144p.
SANTOS, J. Análise da birrefringência intrínseca do colágeno em tendões de eqüinos submetidos a tendinite. 2004. 42f. Dissertação (Mestrado em Medicina Veterinária) Faculdade de Ciências Agrárias e Veterinárias, Universidade Estadual Paulista, Jaboticabal, SP.

SMITH, R.K.W.; CAUVIN, E.R.J. Ultrassonography of the metacarpus and metatarsus. In: KIDD, J.A.; LU, K.G.; FRAZER, M.L. (Eds.). Atlas of equine ultrassonography. Chinchester: John Wiley \& Sons, 2014. p.73.

SPIESZ, E.M.; THORPE, C.T.; THURNER, P.J. et al. Structure and collagen crimp patterns of functionally distinct equine tendons, revealed by quantitative polarised light microscopy (qPLM). Acta Biomater., v.70, p.281-292, 2018.

VIDAL, B.C.; CARVALHO, H.F. Aggregational state and molecular order of tendons as a function of age. Matrix, v.10, p.48-57, 1990.

WAGELS, R.; RÜHMANN, K.; STADLER, P. et al. Feinnadelbiopsie aus den Beugesehnen des Pferdes (Percutaneous core biopsy of the flexor tendons in the horse). Tierärztl. Prax. Großtiere, v.20, p.199-205, 2001.

WERPY, N.M.; DENOIX, J.M. Imaging of the equine proximal suspensory ligament. Vet. Clin. N. Am. Equine Pract., v.28, p.507-525, 2012. 